\title{
Evaluation of Insecticides against Sucking Pests Grown During Kharif
}

\author{
B. Sujatha and T.M. Bharpoda* \\ Department of Agricultural, Entomology, B. A. College of Agriculture, Anand Agricultural \\ University, Anand-388110, Gujarat, India \\ *Corresponding author
}

\begin{tabular}{|c|c|}
\hline & A B S T R A C T \\
\hline $\begin{array}{l}\text { K e y w o r d s } \\
\text { Insecticides, } \\
\text { Aphids, Jassids, } \\
\text { Whitefly, Thrips, } \\
\text { Flower thrips. }\end{array}$ & \multirow{3}{*}{$\begin{array}{l}\text { Investigations were carried out at Agronomy Farm, B. A. College of Agriculture, } \\
\text { Anand Agricultural University, Anand during Kharif, } 2015 \text { for evaluation of } \\
\text { various insecticides on the incidence of sucking pests viz., aphids (Aphis } \\
\text { craccivora Koch), jassids (Empoasca kerri Pruthi), whiteflies (Bemisia tabaci } \\
\text { Gennadius), thrips (Thrips palmi Karny), flower thrips (Megalurothrips usitatus } \\
\text { Bagnall) in green gram. Among the various insecticides evaluated for their field } \\
\text { efficacy against sucking pests, thiamethoxam } 25 \mathrm{WG}(0.01 \%) \text { and imidacloprid } 70 \\
\text { WG (0.014\%) were found more effective followed by dimethoate } 30 \text { EC (0.03\%). } \\
\text { The effectiveness of these treatments also reflected on green gram yield. Higher } \\
\text { Incremental Cost Benefit Ratio (ICBR) was also obtained in these treatments. }\end{array}$} \\
\hline Artic & \\
\hline $\begin{array}{l}\text { Accepted: } \\
\text { 14 September } 2017 \\
\text { Available Online: } \\
\text { 10 October } 2017\end{array}$ & \\
\hline
\end{tabular}

\section{Introduction}

Pulse crops have a unique position in sustainable crop production as they provide highly nutritive food and keep the soil alive as well as productive and also in the agricultural economy of India being the major source of protein in Indian dietary.

The General Assembly of the United Nations has recognised pulses as an essential source of protein and a part of improving nutrition globally and declared 2016 as "The International Year of Pulses" (IYP 2016) (Anon., 2016a).

India is the world's largest producer (18.5 million tonnes), largest importer (3.5 million tonnes) and largest consumer (22.0 million tonnes) of pulses (Anon., 2016b).
The sucking pests like aphids, Aphis craccivora Koch; jassids, Empoasca kerri Pruthi; white flies, Bemisia tabaci Gennadius, thrips, Thrips palmi Karny and flower thrips, Megalurothrips usitatus Bagnall are known to cause significant damage to green gram crop. Whitefly, a potential vector of mung bean yellow mosaic virus (MYMV), can cause losses ranging from $30-70$ per cent (Swaminathan et al., 2012) and 80 to 100 per cent in green gram and black gram (Naimuddin, 2001). Sreekanth (2002) reported that thrips caused at least 40 per cent yield loss in green gram. The annual yield loss due to the insect pests has been estimated to the tune of 30 per cent by Soundararajan and Chitra (2011) in green gram and Justin, et $a l$., (2015) in urd bean and green gram. So 
there is a need to investigate the tools for the sucking pests of green gram to develop an effective management strategy as well as focused on the use of safer chemicals and pesticides.

\section{Materials and Methods}

To evaluate the efficacy of various insecticides viz., Flonicamid 50 WG @ $0.015 \%$, Thiamethoxam $25 \mathrm{WG}$ @ 0.01\%, Imidacloprid 70 WG @ 0.014\%, Clothianidin 50 WDG @ 0.02\%, Diafenthiuron 50 WP @ $0.05 \%$, Profenophos 50 EC @ 0.05\%, Acephate 75 SP @ 0.075\%, Dinotefuran 20 SG@0.008\%, Dimethoate 30 EC @ 0.03\% and Control (water spray) against sucking pests in green gram, the experiment was laid out in a Randomized Block Design with three replications having gross and net plot area 3.0 $\mathrm{m} \times 2.7 \mathrm{~m}$ and $2.4 \mathrm{~m} \times 1.8 \mathrm{~m}$, respectively during Kharif, 2015 at College Agronomy Farm, B. A. College of Agriculture, AAU, Anand. Green gram cultivar, Meha was grown with spacing $45 \mathrm{~cm} \times 15 \mathrm{~cm}$ under recommended agronomical practices.

\section{Method of application}

First spray application of respective insecticides was given on the initiation of the pests and subsequently another one spray was given after 25 days using manually operated knapsack sprayer having duromist nozzle with slight runoff stage. The required chemicals were collected from Department of Entomology and were sprayed.

\section{Method of recording observations}

For recording the observations of aphids, jassids, whiteflies and thrips population was counted from three (upper, middle and lower leaves) and flower thrips per five flowers from the five randomly selected plants in each sector. The observations on sucking pests as well as natural enemies population were recorded prior to one day of first spray as well as after 3,5 and 10 days after each spray.

Yield was recorded after threshing and separating of green gram seeds from each plot weighed separately and converted into quintals per hectare for further statistical analysis. The per cent increase over control was also calculated by following formula:

Yield of treatment - Yield of control Per cent increase

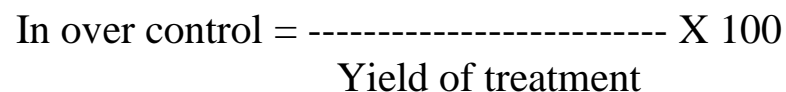

The economics of different treatments were evaluated against sucking pests infesting green gram and Incremental Cost Benefit Ratio (ICBR) was worked out. Total cost of insecticides treatment per hectare was calculated for each treatment based on the prevailing market price. The net gain (yield) over control was calculated by subtracting the yield obtained in control treatment from the yield obtained in each insecticidal treatment. Then, the realization was worked out for each treatment based on increased yield ( $\mathrm{q} / \mathrm{ha}$ ) over control. The net realization (Rs./ha) for each treatment was computed by deducting the cost of insecticides treatment from the value of realization over control. The gross ICBR i.e. net gain in rupees per rupee cost of insecticides treatment was calculated by dividing net profit with the cost of treatment. To calculate the value of net ICBR (NICBR) i.e. additional profit gained per rupee cost of treatment, 1 rupee was subtracted from ICBR obtained in each treatment.

\section{Results and Discussion}

Efficacy of various synthetic insecticides on aphids, $A$. craccivora

The data on aphids population recorded periodically was pooled and presented in Table 1 (column 2) revealed that all the 
insecticidal treatments were significantly superior to control. Among the various insecticides, thiamethoxam 25 WG @ 0.01\% and imidacloprid 70 WG @ 0.014\% were found significantly superior than rest of the insecticidal treatments and recorded lower (0.38 and 0.42 aphids/ 3 leaves, respectively) population. Dimethoate 30 EC @ 0.03\% (1.35), diafenthiuron 50 WP @ 0.05\% (1.46) and flonicamid 50 WG @ 0.015\% (1.54)were at par with each other. Next in order of effectiveness was acephate 75 SP @ 0.075\% followed by profenophos $50 \mathrm{EC} @ 0.05 \%$ and recorded somewhat higher aphids population (2.49 to 2.56 aphids/ 3 leaves). Clothianidin 50 WDG@0.02\% and dinotefuran20 SG @ $0.008 \%$ were comparatively less effective by recording higher (3.04 and 3.95 aphids/ 3 leaves, respectively) population in green gram. However, all the insecticides were significantly more effective as compared to control (10.06). Justin et al., (2015) in black gram and Kabir et al., (2014) in green gram reported higher efficacy of thiamethoxam. Higher efficacy of imidacloprid was also reported in cowpea by Khade et al., (2014) and Reddy et al., (2014). Khutwad et al., (2002) also reported higher efficacy of thiamethoxam and imidacloprid in green gram.

\section{Efficacy of various synthetic insecticides on jassids, E. kerri}

The chronological order of various insecticides based on number of jassids per 3 leaves (given in bracket) was recorded at different periods over sprays Table 1 (column 3)was also pooled thiamethoxam 25 WG @ $0.01 \%(0.11)>$ imidacloprid 70 WG @ $0.014 \%(0.12)>$ flonicamid 50 WG @ $0.015 \%(0.62)>$ dimethoate $30 \mathrm{EC} @ 0.03 \%$ $(0.69)>$ diafenthiuron 50 WP @ 0.05\% (0.78) $>$ acephate 75 SP @ $0.075 \%$ (1.38) > dinotefuran 20 $\quad$ SG @ $0.008 \% \quad(1.43)>$ profenophos 50 EC @ $0.05 \% \quad(1.49)>$ clothianidin 50 WDG @ 0.02\% (2.29) > control (4.30). Among the tested insecticides, thiamethoxam 25 WG @ $0.01 \%$ and imidacloprid 70 WG @ 0.014\% were found significantly superior and recorded lower population of jassids. Next best effective chemicals were flonicamid 50 WG @ $0.015 \%$, dimethoate 30 EC @ $0.03 \%$ and diafenthiuron 50 WP @ 0.05\% against this pest. In addition, there was no significant difference among them. Acephate 75 SP @ $0.075 \%$, dinotefuran 20 SG @ 0.008\% and profenophos 50 EC @ $0.05 \%$ were comparatively less effective insecticides against jassids. Among the tested insecticides, clothianidin 50 WDG @ $0.02 \%$ recorded significantly the highest population and proved to be least effective against jassids infesting green gram. Khattak et al., (2004) reported the highest reduction of jassids in the green gram plots treated with thiamethoxam followed by imidacloprid and diafenthiuron. Sutaria et al., (2010) in soybean, Patel et al., (2012) in cowpea, Sharma and Singh (2015) in urdbean, Iqbal et al., (2013) and Ahirwar et al., (2016) in green gram also reported higher efficacy of thiamethoxam and imidacloprid. Anusha et al., (2014) in cowpea reported higher efficacy of imidacloprid and diafenthiuron and lower efficacy of profenophos. Justin et al., (2015) reported the higher efficacy of thiamethoxam in black gram.

\section{Efficacy of various synthetic insecticides on whiteflies, B. tabaci}

The data on whiteflies population recorded at 3,5 and 10 DAS was also pooled and summarized in Table 1 (column 4). All the insecticidal treatments were significantly superior to control. Thiamethoxam 25 WG @ $0.01 \%$ (0.06/ 3 leaves) and imidacloprid 70 WG @ 0.014\% (0.08) treated plots recorded significantly lower population of whiteflies and found more effective chemicals. 
Diafenthiuron 50 WP @ 0.05\% (0.36) was next best effective insecticide and at par with flonicamid 50 WG @ $0.015 \%$ (0.46). Dimethoate 30 EC @0.03\%, clothianidin 50 WDG @ 0.02\%, acephate 75 SP @ 0.075\% and profenophos 50 EC @ $0.05 \%$ were next in order and also recorded lower (0.89 to 0.99/ 3 leaves) population of whiteflies. Further, these chemicals were at par with each other so far their effectiveness is concerned. Among all the insecticides, dinotefuran 20 SG @ $0.008 \%$ proved to be least effective by recording the highest (1.52) whiteflies population in green gram. Ganapathy and Karuppiah (2005) in green gram, Patel et al., (2012) in cowpea, Gotyal and Prasad (2013) in soybean and Yadav et al., (2015) in black gram reported minimum population of whiteflies in thiamethoxam treated plots.

Muhammad et al., (2002), Sreekanth et al., (2004), Khattak et al., (2004) and Shah et al., (2007) reported higher efficacy of imidacloprid to control whiteflies in green gram. The higher effectiveness of diafenthiuron on whiteflies was reported by Gopalaswamy et al., (2012). Mandal et al., (2015) in green gram and Parmar et al., (2015) in black gram also tested the clothianidin on this pest for its effectiveness.

\section{Efficacy of various synthetic insecticides on thrips, $T$. palmi}

The data on thrips population recorded at different periods over sprays was also pooled and presented in Table 1 (column 5). The chronological order of various insecticides based on number of thrips per three leaves (given in bracket) was: thiamethoxam $25 \mathrm{WG}$ @ 0.01\% (0.48)> imidacloprid 70 WG @ 0.014\% (0.54) > diafenthiuron 50 WP @ $0.05 \%$ (2.81)> flonicamid 50 WG @ 0.015\% (3.03) > dimethoate 30 EC @ 0.03\% (3.15) > acephate 75 SP @ $0.075 \% \quad(5.31)>$ profenophos 50 EC @ $0.05 \% \quad(5.45)>$ clothianidin 50 WDG @ $0.02 \%$ (5.60) > dinotefuran 20 SG @ 0.008\% (7.85) > control (12.17). Among the tested insecticides, thiamethoxam 25 WG @ $0.01 \%$ and imidacloprid 70 WG @ 0.014\% were found significantly superior and recorded lower population of thrips. Diafenthiuron 50 WP @ $0.05 \%$, flonicamid 50 WG @ 0.015\% and dimethoate 30 EC @ $0.03 \%$ were mediocre in their effectiveness against the pest. Rest of the insecticides i.e., acephate 75 SP @ 0.075\%, profenophos 50 EC @ 0.05\% and clothianidin 50 WDG @ 0.02\% were comparatively less effective insecticides against thrips. Among the tested insecticides, dinotefuran 20 SG @ $0.008 \%$ recorded significantly the highest population and proved to be least effective against thripsinfesting green gram. Ahirwar et al., (2016) reported the higher efficacy of thiamethoxam against thrips in green gram. Kaushik et al., (2015) and Anusha et al., (2014) in cowpea and Nataraja et al., (2014) in groundnut also reported higher efficacy of thiamethoxam and imidacloprid followed by diafenthiuron. Damasia et al., (2013) reported the higher effectiveness of dimethoate against thrips in green gram followed by thiamethoxam and imidacloprid.

\section{Efficacy of various synthetic insecticides on flower thrips, $M$. usitatus}

The data on flower thrips population recorded periodically was pooled and presented in Table 1 (column 6). It is clearly indicated that all the insecticidal treatments significantly differed from the control. Among the various insecticides, thiamethoxam 25 WG @ 0.01\% (0.33) was found significantly superior than the rest of the insecticides under study and at par with imidacloprid 70 WG @ 0.014\% (0.46). Diafenthiuron 50 WP @ 0.05\% (1.11), flonicamid 50 WG @ 0.015\% (1.19) and dimethoate 30 EC @ 0.03\% (1.35) stood next in order so far their effectiveness against flower thrips is concerned. 
Table.1 Efficacy of insecticides against different sucking pests in green gram in Kharif (Pooled over periods and sprays)

\begin{tabular}{|c|c|c|c|c|c|}
\hline \multirow[b]{2}{*}{ Treatments } & \multicolumn{4}{|c|}{ No. of sucking pests/ 3 leaves } & \multirow{2}{*}{$\begin{array}{c}\text { No. of } \\
\text { flower } \\
\text { thrips/ } 5 \\
\text { flowers }\end{array}$} \\
\hline & Aphids & Jassids & $\begin{array}{l}\text { Whiteflie } \\
\text { s }\end{array}$ & Thrips & \\
\hline 1 & 2 & 3 & 4 & 5 & 6 \\
\hline Flonicamid 50 WG $0.015 \%$ & $\begin{array}{l}1.43 \mathrm{~b} \\
(1.54)\end{array}$ & $\begin{array}{l}1.06 \mathrm{~b} \\
(0.62)\end{array}$ & $\begin{array}{l}0.98 \mathrm{~b} \\
(0.46)\end{array}$ & $\begin{array}{l}1.88 \mathrm{~b} \\
(3.03)\end{array}$ & $\begin{array}{l}1.30 \mathrm{~b} \\
(1.19)\end{array}$ \\
\hline $\begin{array}{l}\text { Thiamethoxam } 25 \mathrm{WG} \\
0.01 \%\end{array}$ & $\begin{array}{l}0.94 \mathrm{a} \\
(0.38)\end{array}$ & $\begin{array}{l}0.78 \mathrm{a} \\
(0.11)\end{array}$ & $\begin{array}{l}0.75 \mathrm{a} \\
(0.06)\end{array}$ & $\begin{array}{l}0.99 \mathrm{a} \\
(0.48)\end{array}$ & $\begin{array}{l}0.91 \mathrm{a} \\
(0.33)\end{array}$ \\
\hline $\begin{array}{l}\text { Imidacloprid } 70 \mathrm{WG} \\
0.014 \%\end{array}$ & $\begin{array}{l}0.96 \mathrm{a} \\
(0.42) \\
\end{array}$ & $\begin{array}{l}0.79 \mathrm{a} \\
(0.12) \\
\end{array}$ & $\begin{array}{l}0.76 \mathrm{a} \\
(0.08) \\
\end{array}$ & $\begin{array}{l}1.02 \mathrm{a} \\
(0.54)\end{array}$ & $\begin{array}{l}0.98 \mathrm{a} \\
(0.46) \\
\end{array}$ \\
\hline $\begin{array}{l}\text { Clothianidin } 50 \text { WDG } \\
0.02 \%\end{array}$ & $\begin{array}{l}2.06 \mathrm{~d} \\
(3.74)\end{array}$ & $\begin{array}{l}1.67 \mathrm{~d} \\
(2.29)\end{array}$ & $\begin{array}{l}1.19 \mathrm{c} \\
(0.92)\end{array}$ & $\begin{array}{l}2.47 \mathrm{c} \\
(5.60)\end{array}$ & $\begin{array}{l}2.10 \mathrm{~d} \\
(3.91)\end{array}$ \\
\hline Diafenthiuron 50 WP $0.05 \%$ & $\begin{array}{l}1.40 \mathrm{~b} \\
(1.46)\end{array}$ & $\begin{array}{l}1.13 \mathrm{~b} \\
(0.78)\end{array}$ & $\begin{array}{l}0.93 \mathrm{~b} \\
(0.36)\end{array}$ & $\begin{array}{l}1.82 \mathrm{~b} \\
(2.81)\end{array}$ & $\begin{array}{l}1.27 \mathrm{~b} \\
(1.11)\end{array}$ \\
\hline Profenophos 50 EC $0.05 \%$ & $\begin{array}{l}1.75 \mathrm{c} \\
(2.56) \\
\end{array}$ & $\begin{array}{l}1.41 \mathrm{c} \\
(1.49) \\
\end{array}$ & $\begin{array}{l}1.22 \mathrm{c} \\
(0.99)\end{array}$ & $\begin{array}{l}2.44 \mathrm{c} \\
(5.45) \\
\end{array}$ & $\begin{array}{l}1.77 \mathrm{c} \\
(2.63) \\
\end{array}$ \\
\hline Acephate 75 SP $0.075 \%$ & $\begin{array}{l}1.73 \mathrm{c} \\
(2.49) \\
\end{array}$ & $\begin{array}{l}1.37 \mathrm{c} \\
(1.38) \\
\end{array}$ & $\begin{array}{l}1.21 \mathrm{c} \\
(0.96) \\
\end{array}$ & $\begin{array}{l}2.41 \mathrm{c} \\
(5.31) \\
\end{array}$ & $\begin{array}{l}1.70 \mathrm{c} \\
(2.39) \\
\end{array}$ \\
\hline Dinotefuran 20 SG $0.008 \%$ & $\begin{array}{l}2.11 \mathrm{~d} \\
(3.95)\end{array}$ & $\begin{array}{l}1.39 \mathrm{c} \\
(1.43)\end{array}$ & $\begin{array}{l}1.42 \mathrm{~d} \\
(1.52)\end{array}$ & $\begin{array}{l}2.89 \mathrm{~d} \\
(7.85)\end{array}$ & $\begin{array}{l}2.19 \mathrm{~d} \\
(4.30)\end{array}$ \\
\hline Dimethoate 30 EC $0.03 \%$ & $\begin{array}{l}1.36 \mathrm{~b} \\
(1.35)\end{array}$ & $\begin{array}{l}1.09 \mathrm{~b} \\
(0.69)\end{array}$ & $\begin{array}{l}1.18 \mathrm{c} \\
(0.89)\end{array}$ & $\begin{array}{l}1.91 \mathrm{~b} \\
(3.15)\end{array}$ & $\begin{array}{l}1.36 \mathrm{~b} \\
(1.35)\end{array}$ \\
\hline Control (water spray) & $\begin{array}{c}3.25 \mathrm{e} \\
(10.06)\end{array}$ & $\begin{array}{l}2.19 \mathrm{e} \\
(4.30)\end{array}$ & $\begin{array}{l}1.73 \mathrm{e} \\
(2.49)\end{array}$ & $\begin{array}{c}3.56 \mathrm{e} \\
(12.17)\end{array}$ & $\begin{array}{l}2.58 \mathrm{e} \\
(6.16)\end{array}$ \\
\hline
\end{tabular}

\begin{tabular}{|l|r|c|c|c|c|c|}
\hline \multicolumn{2}{|c|}{ F-Test (T) } & Sig & Sig & Sig & Sig & Sig \\
\hline S.Em. & Treatment (T) & 0.06 & 0.04 & 0.04 & 0.07 & 0.06 \\
\hline & Period (P) & 0.03 & 0.01 & 0.02 & 0.03 & 0.03 \\
\hline C. D. at 5\% & Treatment (T) & 0.09 & 0.04 & 0.05 & 0.94 & 0.09 \\
\hline & Period (P) & 0.08 & 0.03 & 0.05 & NS & 0.08 \\
\hline & T x P & NS & 0.10 & NS & NS & NS \\
\hline & C.V.\% & 10.49 & 8.43 & 10.42 & 13.15 & 10.49 \\
\hline
\end{tabular}

Note: Figures in parentheses are retransformed values; those outside are $\sqrt{X+0.5}$ transformed values. Treatment mean with letter(s) in common are not significant by DNMRT at $5 \%$ level of significance within a column; NonSignificant; S: Significant 
Table.2 Impact of insecticides on coccinellids, Chrysoperla spp. and seed yield of green gram

\begin{tabular}{|l|c|c|c|c|}
\hline \multicolumn{1}{|c|}{ Treatments } & $\begin{array}{c}\text { No. of coccinellids } \\
\text { (grubs + adults)/ } \\
\text { plant }\end{array}$ & $\begin{array}{c}\text { No. of Chrysoperla } \\
\text { spp. grubs/ plant }\end{array}$ & $\begin{array}{c}\text { Seed yield } \\
(\mathbf{q} / \text { ha) }\end{array}$ & $\begin{array}{c}\text { Increase over } \\
\text { control (\%) }\end{array}$ \\
\hline \multicolumn{1}{|c|}{$\mathbf{2}$} & $\mathbf{2}$ & $\mathbf{3}$ & $\mathbf{4}$ & $\mathbf{5}$ \\
\hline Flonicamid 50 WG 0.015\% & $1.14(0.80)$ & $1.05(0.60)$ & $8.64 \mathrm{bcde}$ & 28.59 \\
\hline Thiamethoxam 25 WG 0.01\% & $1.24(1.04)$ & $1.07(0.64)$ & $10.26 \mathrm{a}$ & 39.86 \\
\hline Imidacloprid 70 WG 0.014\% & $1.25(1.06)$ & $1.14(0.80)$ & $9.80 \mathrm{ab}$ & 37.04 \\
\hline Clothianidin 50 WDG 0.02\% & $1.09(0.69)$ & $0.92(0.35)$ & $7.79 \mathrm{de}$ & 20.80 \\
\hline Diafenthiuron 50 WP 0.05\% & $1.13(0.78)$ & $1.03(0.56)$ & $8.87 \mathrm{bcd}$ & 30.44 \\
\hline Profenophos 50 EC 0.05\% & $1.07(0.64)$ & $1.00(0.50)$ & $8.03 \mathrm{de}$ & 23.16 \\
\hline Acephate 75 SP 0.075\% & $1.17(0.87)$ & $1.06(0.62)$ & $8.41 \mathrm{cde}$ & 26.63 \\
\hline Dinotefuran 20 SG 0.008\% & $1.26(1.09)$ & $1.16(0.85)$ & $7.41 \mathrm{e}$ & 16.73 \\
\hline Dimethoate 30 EC 0.03\% & $1.11(0.73)$ & $1.00(0.50)$ & $9.42 \mathrm{abc}$ & 34.50 \\
\hline Control (water spray) & $1.50(1.75)$ & $1.17(0.87)$ & $6.17 \mathrm{f}$ & - \\
\hline
\end{tabular}

\begin{tabular}{|l|r|c|c|c|c|}
\hline \multicolumn{2}{|c|}{ F-Test (T) } & NS & NS & Sig & - \\
\hline S.Em. \pm & Treatment (T) & 0.08 & 0.06 & 0.39 & - \\
\hline & Period (P) & - & - & - & - \\
\hline & T x P & - & - & - & - \\
\hline C. D. at 5\% & Treatment (T) & 0.24 & 0.18 & 1.17 & - \\
\hline & Period (P) & - & - & - & - \\
\hline & T x P & - & - & - & - \\
\hline & C.V.\% & 20.24 & 9.25 & 8.00 & - \\
\hline
\end{tabular}

Note: Figures in parentheses are retransformed values; those outside are $\sqrt{X+0.5}$ transformed values. Treatment mean with letter(s) in common are not significant by DNMRT at $5 \%$ level of significance within a column; NonSignificant; S: Significant

Table.3 Economic of various synthetic insecticides used for control of sucking pests infesting green gram

\begin{tabular}{|c|c|c|c|c|c|c|c|c|}
\hline $\begin{array}{c}\text { Insecticides } \\
(\%)\end{array}$ & $\begin{array}{c}\text { Conc. } \\
(\%)\end{array}$ & $\begin{array}{c}\text { Total cost } \\
\text { treatment } \\
(\text { Rs./ha) }\end{array}$ & $\begin{array}{c}\text { Yield of } \\
\text { seed } \\
(\mathbf{q} / \mathbf{h a})\end{array}$ & $\begin{array}{c}\text { Net } \\
\text { gain } \\
\text { over } \\
\text { control } \\
(\mathbf{q} / \mathbf{h a})\end{array}$ & $\begin{array}{c}\text { Realizati } \\
\text { on } \\
(\text { Rs./ha) }\end{array}$ & $\begin{array}{c}\text { Net } \\
\text { Realization } \\
(\text { Rs./ha) }\end{array}$ & ICBR & NICBR \\
\hline 1 & 2 & $\mathbf{3}$ & $\mathbf{4}$ & $\mathbf{5}$ & $\mathbf{6}$ & $\mathbf{7}$ & $\mathbf{8}$ & $\mathbf{9}$ \\
\hline
\end{tabular}

\begin{tabular}{|c|c|c|c|c|c|c|c|c|}
\hline Flonicamid $50 \mathrm{WG}$ & 0.015 & 4094 & 8.64 & 2.47 & 14820 & 10726 & $1: 2.62$ & $1: 1.62$ \\
\hline Thiamethoxam 25 WG & 0.01 & 2784 & 10.26 & 4.09 & 24540 & 21756 & $1: 7.81$ & $1: 6.81$ \\
\hline Imidacloprid $70 \mathrm{WG}$ & 0.014 & 2906 & 9.80 & 3.63 & 21780 & 18874 & $1: 6.49$ & $1: 5.49$ \\
\hline Clothianidin $50 \mathrm{WDG}$ & 0.02 & 7104 & 7.79 & 1.62 & 9720 & 2616 & 1:0.37 & 1:-0.63 \\
\hline Diafenthiuron 50 WP & 0.05 & 5084 & 8.87 & 2.70 & 16200 & 11116 & $1: 2.19$ & $1: 1.19$ \\
\hline Profenophos 50 EC & 0.05 & 2024 & 8.03 & 1.86 & 11160 & 9136 & $1: 4.51$ & $1: 3.51$ \\
\hline Acephate 75 SP & 0.075 & 2288 & 8.41 & 2.24 & 13440 & 11152 & $1: 4.87$ & $1: 3.87$ \\
\hline Dinotefuran $20 \mathrm{SG}$ & 0.008 & 4784 & 7.41 & 1.24 & 7440 & 2656 & $1: 0.56$ & 1:-0.44 \\
\hline Dimethoate $30 \mathrm{EC}$ & 0.03 & 1648 & 9.42 & 3.25 & 19500 & 17852 & $1: 10.83$ & $1: 9.83$ \\
\hline Control (water spray) & - & - & 6.17 & - & - & - & - & - \\
\hline \multicolumn{9}{|c|}{$\begin{array}{l}\text { Market price of green gram grain: Rs. } 60 / \mathrm{kg} \text { (Rs. } 6000 / \text { quintal) } \\
\text { Labour charges: For spraying Rs. } 296 / \mathrm{labour} / \mathrm{day} \\
\text { Two labour per hectare required for each spray, two sprays were given ( } 500 \text { litre spray solution is required for one spray for } \\
\text { one hectare) }\end{array}$} \\
\hline
\end{tabular}


Acephate $75 \quad$ SP $\quad @ \quad 0.075 \% \quad(2.39)$, profenophos 50 EC @ $0.05 \%$ (2.63), clothianidin 50 WDG @0.02\% (3.91) and dinotefuran 20 SG @ 0.008\% (4.30) were found comparatively less effective in controlling flower thrips population. However, all the insecticides were significantly more effective as compared to control (6.16). Higher efficacy of imidacloprid and dimethoate against flower thrips in cowpea was reported by Oyewale $e t$ al., (2014).

Effect of various synthetic insecticides on Coccinellids (grubs and adults) and Chrysoperla spp. (grubs)

The data on coccinellids recorded periodically was also pooled and summarized in Table 2 (Column 2). The chronological order of various synthetic insecticides in comparison to control based on population of coccinellids (grubs and adults) per plant (in bracket) was: control (1.75) > dinotefuran 20 SG @ 0.008\% (1.09) > imidacloprid 70 WG @ 0.014\% (1.06) >thiamethoxam 25 WG @ $0.01 \%$ (1.04) > acephate 75 SP @ 0.075\% (0.87) > flonicamid 50 WG @ $0.015 \%(0.80)>$ diafenthiuron 50 WP @ 0.05\% (0.78) > dimethoate 30 EC @ $0.03 \% \quad(0.73)>$ clothianidin 50 WDG @ 0.02\% (0.69) > profenophos 50 EC @ 0.05\% (0.64). As far as ANOVA presented in Table 36 is concerned, all the treatments including control were at par with each other. Numerical data showed that there was slight reduction of population in the plots treated with synthetic insecticides (0.64 to $1.09 /$ plant) when compared with control plots (1.75).The population of Chrysoperla spp. (grubs) was observed at 10 DAS and summarized in the Table 2 (Column 3 ) revealed that all the synthetic insecticides under investigation were more or less did not impose any significant adverse effect on the activity of this predator in green gram with reduction in the population of this natural enemy in the plots receiving synthetic insecticides $(0.35$ to $0.85 /$ plant $)$ than the control plots. Mithu et al., (2015) in cowpea and green gram, Bharpoda et al., (2014) in Bt cotton, Chakraborty et al., (2013) in pulse crops as well as Sitaramaraju et al., (2010) in cotton reported less toxicity of thiamethoxam and imidacloprid; Pawar and Bharpoda (2013) reported the less toxicity of flonicamid against coccinellids in safflower. Scanty information is available on Chrysoperla spp. (grubs) in green gram.

Impact of various synthetic insecticides on seed yield, per cent increase in yield over control and economics

The efficacy of various chemicals against sucking pests reflected on seed yield (Table 2 and Column 4) as well as per cent increase in yield over control (Table 2 and Column 5) of green gram. Plots treated with different insecticides yielded significantly higher seed yield (7.41 to $10.26 \mathrm{q} /$ ha) than control (6.17). The chronological order of various insecticidal treatments in comparison to control based on seed yield (q/ ha) as well as per cent increase in yield over control was: thiamethoxam 25 WG @ $0.01 \%>$ imidacloprid 70 WG @ 0.014\% > dimethoate 30 EC @ 0.03\% >diafenthiuron 50 WP @ $0.05 \%>$ flonicamid 50 WG @ 0.015\%> acephate 75 SP @ 0.075\% > profenophos 50 EC @ $0.05 \%>$ clothianidin 50 WDG @ $0.02 \%>$ dinotefuran 20 SG @ 0.008\% > control. Thiamethoxam 25 WG @ 0.01\% treated plots harvested significantly the highest yield and was at par with imidacloprid 70 WG @ 0.014\% and dimethoate 30 EC @ $0.03 \%$. Rest of the insecticides i.e. diafenthiuron 50 WP @ 0.05\%, flonicamid 50 WG@ 0.015\%, acephate 75 SP @ 0.075\%, profenophos 50 EC @ $0.05 \%$ and clothianidin 50 WDG @ 0.02\% were at par with each other. Among the synthetic insecticides, dinotefuran20 SG @ 0.008\% recorded the 
lowest yield. Maximum yield loss could be avoided with spray application of thiamethoxam 25 WG @ 0.01\%, imidacloprid 70 WG @0.014\%, dimethoate 30 EC @ $0.03 \%$ and diafenthiuron 50 WP @ $0.05 \%$.

The economics of various synthetic insecticides (Table 3) revealed that the highest $(24,540.00$ Rs./ ha) realization was obtained from the treatment thiamethoxam 25 WG@ $0.01 \%$ followed by imidacloprid 70 WG @ $0.014 \% \quad(21,780.00 \quad$ Rs./ ha $)$, dimethoate 30 EC @ $0.03 \% \quad(19,500.00$ Rs./ha) and diafenthiuron 50 WP @ 0.05\% (16,200.00 Rs./ ha). The highest ICBR was calculated from the plots treated with dimethoate 30 EC @ 0.03\% (1: 10.83). Thiamethoxam 25 WG @ 0.01\% (1:7.81), imidacloprid 70 WG @0.014\% (1:6.49), acephate 75 SP @ $0.075 \%$ (1:4.87) and profenophos 50 EC @ 0.05\% (1:4.51) also recorded higher ICBR. Dinotefuran 20 SG @ $0.008 \%$ (1:0.56) and clothianidin 50 WDG @ $0.02 \%$ (1:0.37) recorded lower ICBR and proved to be non-economical insecticidal treatments. The highest (9.83) NICBR was calculated from the plots treated with dimethoate 30 EC @ 0.03\%. Thiamethoxam 25 WG @ 0.01\% (6.81) and imidacloprid 70 WG@ 0.014\% (5.49) also recorded higher NICBR. Dinotefuran 20 SG @ 0.008\% (0.56) and clothianidin 50 WDG @ 0.02\% (0.37) recorded lower NICBR and found not much economical insecticidal treatments.

Sreekanth et al., (2003), Shah et al., (2007) and Hossain et al., (2013) from green gram and Gopalaswamy et al., (2012) in black gram reported higher yield in the plots treated with imidacloprid. Mandal et al., (2015) reported higher yield and net return of green gram in thiamethoxam followed by dimethoate and clothianidin. Ahirwar et al., (2016) reported higher yield of green gram in thiamethoxam followed by imidacloprid, dimethoate and acephate. Kumar et al., (2007) reported that dimethoate in black gram was more effective and economical. Bairwa et al., (2006) reported higher yield and higher ICBR in plots treated with dimethoate followed by acephate and imidacloprid in moth bean. Sharma and Singh (2015) reported higher yield in plots treated with imidacloprid followed by thiamethoxam in urdbean.

\section{References}

Ahirwar, B., Bhowmick, A. K., Gupta, P. K. and Khan, M. A. (2016). Efficacy of insecticides against sucking pests and yield of mung bean. Annals of Plant Protection Sciences, 24 (1): 34 - 37.

Anonymous, 2016a. http://www.ipga.co.in/ iyop_2016.

Anonymous, 2016b. http://www.thehindu businessline.com/economy/agri-business/ 2016-will-be-international-year-of-pulses/ article5494209.ece

Anusha, Ch., Balikai, R. A. and Patil, R. H. 2014. Management of cowpea pests through newer and conventional insecticides. International Journal of Agricultural and Statistics Sciences, 10(1): $157-160$.

Bairwa, D. K., Sharma, J. K. and Kumawat, K. C. 2006. Efficacy of insecticides, bio pesticide and plant products against whitefly, Bemisia tabaci on moth bean, Vigna aconitifolia. Indian Journal of Plant Protection, 34 (2): $210-212$.

Bharpoda, T. M., Patel, N. B., Thumar, R. K., Bhatt, N. A., Ghetiya, L. V., Patel, H. C. and Borad, P. K. 2014. Evaluation of insecticides against sucking insect pests infesting Bt cotton BG- II. The Bioscan, 9 (3): 977- 980.

Chakraborty, D., Korat, D. M. and Saneera, E. K. 2013. Relationship between predatory coccinellids and their hosts on three different pulse crops. Insect Environment, 19 (1): 63 - 64.

Damasia, D. M., Raghvani, B. R., Kathiria, J. 
B. and Kabaria, B. B. 2013. Efficacy of different insecticides against the thrips infesting summer green gram. Pestology, 37 (7): 17 - 21.

Ganapathy, T., and Karuppiah, R. 2005. Evaluation of new insecticides for the management of whitefly (Bemisia tabaci Genn.), mung bean yellow mosaic virus (MYMV) and urdbean leaf crinkle virus (ULCV) diseases in mung bean Vigna radiata (L.) Wilczek. Indian Journal of Plant Protection, 32 (1): 35 38.

Gawande, S. P., and Nagrale, D. T. 2014. Efficacy of Verticillium lecanii for biological control of whitefly, Bemisia tabaci. Indian Journal of Plant Protection, 42 (3): 289 - 291.

Gopalaswamy, S. V. S., Ramana, M. V. and Radha Krishna, Y. 2012. Management of YMV of black gram by chemical control of Bemisia tabaci Gennadius. Annals of Plant Protection Sciences, 20 (2): $358-360$.

Gotyal, B. S., and Prasad, S. K. 2013. Management and evaluation of Soybean cultivars against yellow mosaic virus disease transmitted by Bemisia tabaci Genn. in relation to weather variables. Annals of Plant Protection Sciences, 21 (2): $299-301$.

Hossain, M. A., 2013. Development of insecticide application schedule for management of flower thrips and pod borer in mung bean (Vigna radiata L.). Bangladesh Journal of Agricultural Research, 38 (1): 19 - 28.

Iqbal, J., Muhammad, N., Muhammad, S. A., Muhammad, M. F. and Muhammad W. U. Hassan. 2013. Comparative efficacy of some insecticides against sucking insect pests on mung bean, Vigna radiata (L.) Wilczek. Gomal University Journal of Research, 29 (1): 31 - 37.

Justin, G. L. C., Anandhi, P. and Jawahar, D. 2015. Management of major insect pests of black gram under dry land conditions. Journal of Entomology and Zoology Studies, 3 (1): 115 - 121.

Kabir, M. M., Hossain, M. A., Farhat, T., Yasmin, S., Niaz, Md. and Farhat, R. 2014. Effect of different botanicals and chemicals on the incidence of sucking insect pests and their impact on mosaic disease of mung bean. International Journal of Innovative Research and Development, 3 (5): 62 - 68.

Kaushik, A. K., Yadav, S. K. and Srivastava, P. 2015. Comparative efficacy of some insecticides for thrips control in cowpea (Vigna unguiculata L.). Annals of Plant Protection Sciences, 23 (2): 294 - 297.

Khade, K. N., Undirwade, D. B., Tembhurne, R. D. and Lande, G. K. 2014. Biorational management of sucking pests of cowpea Vigna sinensis L. Trends in Biosciences, 7 (20): 3212 3217.

Khattak, M. K., Ali, S., Chishti, I. J., Saljiki, A. R. and Hussain, A. S. 2004. Efficacy of certain insecticides against some sucking pests of mung bean (Vigna radiata L.). Pakistan Entomology, 26 (1): 75 - 80.

Khutwad, D. S., Nakat, R. V. and Chavan, B. P. 2002. Seed dressers and foliar sprays on sucking pests of green gram Vigna radiata (L.) Wilczek. Pestology, 26 (7): $57-59$.

Kumar, R., Ali, S. and Chandra, Umesh. 2007. Efficacy and Economics of biopesticides in management of whitefly and tobacco caterpillar in Vigna mungo. Annals of Plant Protection Sciences, 15 (2): 354 - 357.

Mandal, S. K., 2015. Bio-efficacy of novel insecticides against whitefly, Bemisia tabaci in mung bean. Annals of Plant Protection Sciences, 23 (1): 16 - 18.

Mithu, A., Korat, D. M., and Sangle, P. M. 2015. Effect of neonicotinoid insecticides on predatory coccinellids in 
cowpea and green gram. The Bioscan, 10 (3): 1073-1077.

Muhammad, A., Ahmad, T. and Bashir, H. M. 2002. Relative toxicity of different insecticides against whitefly, Bemisia tabaci (Genn.) and black thrips, Caliothrips indicus on NM-92 mung bean, Vigna radiata (L.). Pakistan Journal of Agricultural Sciences, 39 (3): $224-225$.

Naimuddin, 2001. Major viral diseases of pulses and their management, Technical Bulletin No. IIPR/ 2001/ 11, published by Indian Institute of Pulses Research, Kanpur, pp 1 - 22.

Nataraja, M. V., Harish, G., Jastrotia, P., Holajjer, P., Savaliya, S. D. and Gajera, M. 2014. Neo-nicotinoids: A bio rational approach for managing sucking insect-pests of groundnut. Annals of Plant Protection Sciences, 22 (1): 42 48.

Oyewale, R. O., Bamaiyi, L. J., Oparaeke, A. M., and Adamu, R. S. 2014. Evaluation of four insecticide formulations for the management of insect pests of cowpea. African Journal of Food Science and Technology, 5 (8): 180-188.

Parmar, S. G., Naik, M. M., Pandya, H. V., Rathod, N. K., Patel, S. D., Dave, P. P. and Saiyad, M. M. 2015. Bio-Efficacy of some insecticides against pest complex of blackgram [Vigna mungo (L.) Hepper]. International Journal of Plant Protection, 8 (1): 162 168.

Patel, P. S., Patel, I. S., Panickar, B. and Ravindrababu, Y. 2012. Management of sucking pests of cowpea through seed treatment. Trends in Biosciences, 5 (2): $138-139$.

Pawar, S. R., and Bharpoda, T. M. 2013. Efficacy of botanicals and synthetic insecticides against aphid, Uroleucon compositae Theobald infesting safflower. Pesticide Research Journal,
25 (1): 29-35.

Reddy, S. D., Pushpa Latha, M., Chowdary, R. L. and Kumar, R. L. 2014. Efficacy of chemical and botanical against cowpea aphid [Aphis craccivora (Koch)]. BIOINFOLET, 11 (3 B): 853 854.

Shah, M. J., Ahmad, A., Hussain, M., Yousaf, M. M. and Ahmad, B. 2007. Efficiency of different insecticides against sucking insect-pest complex and effect on the growth and yield of mung bean Vigna radiata (L.). Pakistan Entomology, 29 (2): $83-85$.

Sharma, S. R., and Singh, D. P. 2015. Competitive studies of insecticides for the control of sucking pests in urdbean (Vigna mungo) in relation to yield. International Journal of Plant Protection, 8 (2): 393 - 396.

Sitaramaraju, S., Prasad, N. V. V. S. D. and Krishnaiah, P. V. 2010. Bio efficacy of insecticides as seed dressers against early sucking pests of cotton. Pestology, 34 (2): 21-25.

Soundararajan, R. P., and Chitra, N. 2011. Effect of bio inoculants on sucking pests and pod borer complex in urdbean. Journal of Bio pesticides, 4(1): 7 - 11.

Sreekanth, M., 2002. Bio-ecology and management of thrips vector(s) of peanut bud necrosis virus (PBNV) in mung bean (Vigna radiata L.) Ph. D. thesis submitted to the Acharya N. G. Ranga Agricultural University, Rajendranagar, Hyderabad, Andhra Pradesh, India, pp. 165.

Sreekanth, M., Sreeramulu, M., Prasad Rao, R. D. V. J., Sarath Babu, B. and Ramesh Babu, T. 2003. Relative efficacy and economics of different imidacloprid schedules against Thrips palmi (Karny), the vector of peanut bud necrosis virus incidence on mung bean Vigna radiata (L.) Wilczek. Indian 
Journal of Plant Protection, 31(1): 43 47.

Sreekanth, M., Sreeramulu, M., Prasad Rao, R. D. V. J., Sarath Babu, B. and Ramesh Babu, T. 2004. Evaluation of certain new insecticides against Thrips palmi (Karny), the vector of peanut bud necrosis virus incidence in mung bean Vigna radiata (L.) Wilczek. International pest control, 46 (6): 315 317.

Steel, R. G. D., and Torrie, J. H. 1980. Principles and procedures of statistics. Publ. McGraw-Hill Book Company, New York. Pp. 137.

Sutaria, V. K., Motka, M. N., Jethva, D. M. and Ramoliya, D. R. 2010. Field efficacy of insecticides against jassid, Empoasca kerri (Pruthi) in soybean. Annals of Plant Protection Sciences, 18 (1): $94-97$.

Swaminathan, R., Singh, K. and Nepalia, V. 2012. Insect pests of green gram Vigna radiata (L.) Wilczek and their management, Agricultural Science, Dr. Godwin Aflakpui (Ed.).

Yadav, S. K., Patel, S., Agnihotri, M. and Bisht, R. S. 2015. Efficacy of insecticides and bio-pesticides against sucking pests in black gram. Annals of Plant Protection Sciences, 23(2): 223 226.

\section{How to cite this article:}

Sujatha, B. and Bharpoda, T.M. 2017. Evaluation of Insecticides against Sucking Pests Grown During Kharif. Int.J.Curr.Microbiol.App.Sci. 6(10): 1258-1268.

doi: https://doi.org/10.20546/ijcmas.2017.610.150 